University of Nebraska - Lincoln

DigitalCommons@University of Nebraska - Lincoln

Biological Systems Engineering: Papers and Publications

Biological Systems Engineering

Fall 1991

\title{
A Conservation Tillage Educational Program
}

\author{
Elbert C. Dickey \\ University of Nebraska at Lincoln, edickey1@unl.edu
}

Paul J. Jasa

University of Nebraska-Lincoln, pjasa1@unl.edu

David P. Shelton

University of Nebraska-Lincoln, dshelton2@unl.edu

Follow this and additional works at: https://digitalcommons.unl.edu/biosysengfacpub

Part of the Biological Engineering Commons

Dickey, Elbert C.; Jasa, Paul J.; and Shelton, David P., "A Conservation Tillage Educational Program" (1991). Biological Systems Engineering: Papers and Publications. 236.

https://digitalcommons.unl.edu/biosysengfacpub/236

This Article is brought to you for free and open access by the Biological Systems Engineering at DigitalCommons@University of Nebraska - Lincoln. It has been accepted for inclusion in Biological Systems Engineering: Papers and Publications by an authorized administrator of DigitalCommons@University of Nebraska Lincoln. 


\section{A Conservation Tillage Educational Program}

Elbert C. Dickey, Paul J. Jasa, and David P. Shelton 


\title{
A Conservation Tillage Educational Program
}

\author{
Elbert C. Dickey,* Paul J. Jasa, and David P. Shelton
}

\begin{abstract}
An educational program was conducted to enhance the adoption of conservation tillage practices in targeted areas to reduce soil erosion and on-farm fuel use. Traditional extension methods such as meetings, field days, demonstrations, and plots were used extensively. In addition, the following nontraditional educational methods were used to achieve project objectives: targeting high priority areas, local program guidance committees, surveys to evaluate perceptions and use of conservation tillage, employment of extension assistants to work in the target areas, use of a rainfall simulator to demonstrate the effectiveness of residue cover in reducing erosion, and small group or "coffee shop" meetings to answer specific questions. With this concentrated educational effort, project goals of a $20 \%$ increase in conservation tillage and a $10 \%$ increase in no-till planting were exceeded during the 5-yr project in the 219000 ha target areas. Using residue cover as a criterion to define conservation tillage, there was a $21.4 \%$ increase in the use of conservation tillage from 1984 to 1988 . In the same time period, no-till use increased threefold. There was a projected annual savings of $1.47 \mathrm{ML}$ of fuel and $59400 \mathrm{~h}$ of labor. The estimated average annual soil loss reduction in the target areas was $2.27 \mathrm{Mt}$ or approximately $10.3 \mathrm{t} \mathrm{ha}^{-1}$.
\end{abstract}

$\mathrm{S}$ on erosion, sedimentation, and subsequent impacts on water quality are major problems associated with Nebraska crop production (NNRC, 1979). Eastern Nebraska has a history of severe soil erosion due primarily to a predominance of steep slopes and highly erodible soils. Some fields have annual soil erosion rates exceeding $225 \mathrm{t} \mathrm{ha}^{-1}$, whereas the average annual allowable soil loss ( $T$ value) is $11.2 \mathrm{t} \mathrm{ha}^{-1}$. Erosion also removes fertilizers and pesticides, thus further contributing to water quality problems.

Conservation tillage is one of the most effective and least costly methods of reducing soil erosion and also conserves labor, fuel, and soil moisture. Any tillage/planting system can be classified as conservation tillage, provided that at least $30 \%$ of the soil is covered with residue following tillage and planting [Conservation Tillage Information Center (CTIC), 1985].

Two deterrents to the adoption of conservation tillage are tradition and lack of experience. Farmer concerns about possible yield decreases, weed control, fertilizer requirements, equipment costs, and soil responses to fewer tillage operations have also delayed implementation of conservation tillage.

E.C. Dickey and P.J. Jasa, L.W. Chase Hall, Univ. of Nebraska, Biological Systems Eng. Dep., Lincoln, NE 68583-0726; and D.P. Shelton, Univ. of Nebraska Northeast Res. and Ext. Center, Concord, NE 68728-0111. Published as Journal Series no. 9386, Agric. Res. Div., Univ. of Nebraska-Lincoln. Received 9 Oct. 1990. *Corresponding author.

Published in J. Agron. Educ. 20:102-107 (1991).
Farmers often are aware that erosion is a problem nationally, but may not recognize it in their own operation. Sheet and rill erosion, two of the most common forms of soil loss, may be largely invisible to farmers (Nowak, 1985). Even when farmers recognize an erosion problem, they may not realize that residue management practices can reduce soil losses, or, they do not have the appropriate information about what constitutes conservation tillage. According to the 1982 Natural Resources Inventory, for the nation as a whole, the percentage of cropland treated with one or more conservation practices appears to decline with successively higher potential erosion (Committee on Conservation Needs and Opportunities, 1986). Because of the abovementioned reasons, the need for a specific, locally targeted extension educational program became apparent.

The overall goal of this conservation tillage educational project was to enhance the adoption of soil, water, and energy conservation practices. Specific goals to be attained within the target areas were to:

1. Increase by $20 \%$ the area on which conservation tillage was used

2. Increase by $10 \%$ the area on which no-till planting was used

This project was designed to be implemented in selected high priority areas. Targeting priority areas allowed efficient use of funds and other resources to achieve substantial impacts in a relatively short period of time.

\section{METHODOLOGY}

\section{Target Area Selection}

The University of Nebraska Cooperative Extension (CE), with input from the Soil Conservation Service (SCS), the Natural Resources Districts (NRDs), and other state agencies, selected three target areas. These areas involved seven eastern Nebraska counties, encompassing 219000 ha of row crop production. Criteria for selection of the target areas included potential soil erosion, farmer use and interest in conservation tillage, and the local extension agent's desire to make conservation tillage a major educational component of the county extension program. The primary thrust of the project was inside the target areas. However, publicity and educational activities pertaining to the project generated audience interest both in counties adjacent to the target areas and statewide.

Abbreviations: CE, Cooperative Extension; SCS, Soil Conservation Service; NRDs, Natural Resources Districts; USLE, universal soil loss equation. 


\section{Extension Assistants}

Two extension assistants were employed to conduct day-to-day project activities, develop and coordinate educational programs, and work directly, often one-onone, with producers, implement dealers, chemical company representatives, and other agency personnel. These assistants served as liaison between university subject matter specialists, local extension personnel, and producers. The assistants also provided direct support to farmers needing equipment adjustments or other technical help when adopting conservation tillage systems. Extension specialists from a broad range of disciplines, extension agents in the target areas, and the project leaders provided additional programming support.

\section{Local Guidance Committees}

Local committees similar to those described by Bauder and Hickman (1988) were formed to provide guidance in defining educational needs and determining educational methods best suited for each target area. Committee membership included farmers, agribusiness and media representatives, and personnel from local NRDs, SCS, and CE offices. With committee guidance, programs were tailored and changed continually to meet specific needs. Farmers who were not using conservation tillage were invited to participate in guidance committee organizational meetings. The contributions and ideas from these farmers proved valuable, and activities were designed to overcome concerns and myths often expressed by nonusers.

\section{Documentation and Evaluation}

Documentation of conservation tillage use and farmer attitudes regarding conservation tillage was desired early in the project. Additionally, baseline data were needed to measure project impacts. Therefore, both a random mail survey and a separate random field survey were conducted in 1984 (Dickey et al., 1987). The survey results were used to design educational programs (Rockwell et al., 1990). Mail and field surveys were also conducted in 1988 to help determine the impacts of the project. The 1988 mail survey was sent to the farmers who responded to the 1984 random survey, and paired statistical comparisons were made at the $10 \%$ level of significance.

The 1984 surveys indicated that $50 \%$ of the respondents in the target areas felt they were using conservation tillage, but residue cover measurements showed that less than $5 \%$ of 294 randomly selected fields surveyed actually met the $30 \%$ residue cover criterion (Dickey et al., 1987). The mail survey showed that most producers were no longer plowing and implied that conservation tillage was associated with not using the moldboard plow, even though the questionnaire defined conservation tillage in terms of residue cover and contained photographs of the minimum level of residue. Respondents indicated concerns about the cost and effectiveness of herbicide programs, and the cost and performance of conservation
Table 1. Educational activities used in the conservation tillage project.

\begin{tabular}{|c|c|c|c|c|c|c|}
\hline \multirow[b]{2}{*}{ Activity } & \multicolumn{2}{|c|}{$\begin{array}{l}\text { Inside the } \\
\text { target areas }\end{array}$} & \multicolumn{2}{|c|}{$\begin{array}{l}\text { Adjacent to } \\
\text { target areas } \\
\end{array}$} & \multicolumn{2}{|c|}{ Total } \\
\hline & No. & Attend & No. & Attend & No. & Attend \\
\hline $\begin{array}{l}\text { Area conservation tillage } \\
\text { meetings }\end{array}$ & 15 & 1480 & 17 & 1410 & 32 & 2890 \\
\hline Coffee shop meetings & 33 & 407 & 16 & 251 & 49 & 658 \\
\hline Other meetings & 13 & 376 & 10 & 500 & 23 & 877 \\
\hline $\begin{array}{l}\text { Planter/equipment } \\
\text { demonstrations }\end{array}$ & 18 & 793 & 5 & 635 & 23 & 1428 \\
\hline $\begin{array}{l}\text { Rainfall simulator } \\
\text { demonstrations }\end{array}$ & 19 & 1003 & 22 & 2040 & 41 & 3043 \\
\hline Conservation tours & 48 & 1799 & 13 & 652 & 61 & 2451 \\
\hline
\end{tabular}

tillage equipment, especially planters when operating in residue-covered fields.

The local program guidance committees and the survey results were used to develop specific educational programs. These programs emphasized that residue cover, rather than tillage implement, was the most important factor in reducing soil erosion. Activities conducted between December 1983 and March 1989 are summarized in Table 1.

\section{Local Demonstrations}

The guidance committees encouraged the use of demonstration plots. Each year, approximately 50 to 75 farmers cooperated to show different aspects of conservation tillage. Signs, which included the cooperator's name and a project logo, were placed adjacent to the demonstration fields or plots. These signs provided project identity and visibility during the entire growing season.

These plots included side-by-side comparisons of no-till planting and conventional tillage/planting systems, various fertilizer application methods, and different herbicide programs. Whole fields of no-till or ridge-plant were used when the local committees felt that field-size treatments would have greater impact. The plots or fields were planted and tilled as appropriate by the cooperating farmer, usually using his equipment. The extension assistants helped with necessary equipment adjustments, herbicide recommendations, and plot layout.

Yield and cost data from the demonstration plots were incorporated into local tours and meetings. Thus, farmers in the area were able to see no-till planting equipment and other conservation tillage equipment in use, could follow the growth of the crop through a season, and had an opportunity to learn what the yield and production costs were for a field or plot in their neighborhood. The data from side-by-side plots provided evidence to dispel the perception that no-till planting would reduce yields and increase costs. For example, the results showed that for corn (Zea mays L.) production, no-till had a crop yield that was equal to or greater than the farmer's conventionally planted system at 28 of the 35 comparison sites. No-till corn was also at least $\$ 12.35 \mathrm{ha}^{-1}$ less expensive in 25 of the 35 comparisons (Jasa and Dickey, 1990). 


\section{Conservation Tours for Farmers}

Most tours included a field of corn or grain sorghum [Sorghum bicolor (L.) Moench] no-till planted into soybean residue using conventional planting equipment. A "more difficult" no-till field, such as soybean [Glycine $\max$ (L.) Merr.] into corn residue; a fertility plot; and a herbicide comparison plot were other typical tour stops. The cooperator at each stop described the tillage/ planting system used, the herbicide program, and the solutions to any problems encountered. Extension agents and specialists provided technical support in answering questions. Often, SCS personnel presented information on terraces, residue cover, and other methods of erosion control. On some tours, the cooperator's planter or another appropriate conservation tillage implement was available for attendees to view and discuss. Often, a handout outlining herbicide and fertilizer programs and other pertinent field data was provided.

\section{Conservation Tours for Agribusiness}

Some guidance committee members expressed concern that local lending institutions, landlords, and chemical/equipment dealers did not understand conservation tillage or did not feel it could be successful. In addition, some of the local media representatives did not have the depth of understanding necessary to report accurately on conservation tillage systems. For these reasons, special tours were conducted for area agribusiness and media representatives. Discussions addressed specific misconceptions voiced by agribusiness.

1. Equipment dealers saw farmers using old and new, modified and unmodified equipment in residuecovered fields. They learned that conservation tillage is defined by the amount of residue remaining on the soil surface after planting, not by the type of equipment used, and that much of their equipment could be used for conservation tillage.

2. Lenders and landlords sometimes had been hesitant to support conservation tillage programs, especially no-till, because of the perceived economic risks. They examined fields that had been successfully farmed with conservation tillage, some for more than $10 \mathrm{yr}$, and were given cost and yield figures that area farmers had compiled over several years.

3. Chemical dealers thought that "special" fertilizer and herbicide programs were needed, especially for no-till. They learned that this was generally not true.

4. The media representatives were in a unique position to hear views of agribusiness and successful farmers toward conservation tillage while getting facts on the economic, engineering, and agronomic elements from extension specialists.

\section{Planting and Equipment Demonstrations-Field Days}

Many farmers expressed a hesitation in adopting conservation tillage because of perceived high investments in new equipment. Producers were unaware that much of their currently owned equipment, especially planters, could be used without modification. As a result, demonstrations were conducted with farmers already using conservation tillage showing their planters operating in no-till, ridge-plant, or tilled conditions where appreciable residue remained. Time was available for farmers to ask technical questions of either extension personnel or cooperating implement dealers. Variations of these field days included demonstrations of no-till drills, no-till and ridge-till cultivators, and other conservation tillage equipment.

\section{Rainfall Simulator}

A rotating boom rainfall simulator was used to show the effectiveness of residue cover in reducing erosion. Within a uniformly tilled area with little residue, four plots, each $1.5 \mathrm{~m}$ wide by $9.1 \mathrm{~m}$ long, were established. Residue (usually straw) was added to the surface of three plots, resulting in four degrees of residue cover: typically 0 to $5 \%$ (cleanly tilled), 30 and $50 \%$ (representing varying amounts of tillage), and 90 to $100 \%$ (representing no-till). As rainfall was applied, runoff passed through metal collection devices at the lower end of each plot allowing visual comparisons of both soil erosion and water runoff. Generally runoff from the residue-free plots occurred first and was very dark in color, showing extensive erosion. In contrast, the runoff from the residue-covered plots was relatively clear. While originally designed as a research tool in Nebraska (Swanson, 1965), the rainfall simulator proved to be a very effective educational tool as well. A similar observation was made by Dillaha et al. (1988).

\section{Area Conservation Tillage Meetings}

These meetings were generally full-day and in-depth, similar to those described by Riehle (1986). While extension specialists representing a variety of disciplines presented most of the program, extension agents reported on results, demonstrations, and/or experiences in the area. Local farmers also made presentations about their specific conservation tillage system. Generally these farmers were cooperators who had hosted a field day or plot tour. The extension assistants often helped the farmer prepare visuals and suggested specific items to be included that would be of interest to other farmers. The farmer presentations were well received; meeting attendees indicated that this aspect of the program should be extended (Dickey et al., 1991).

A conservation tillage proceedings with the presentations from all the meetings was printed annually and distributed to meeting participants. Yield and cost data from the demonstration plots were also included as an article in the proceedings each year. Evaluation forms were used at these meetings to provide additional guidance for the overall educational program.

\section{Coffee Shop Meetings}

Although some time was allocated for questions at the area conservation tillage meetings, the format did not 
allow for in-depth personalized assistance, and subject matter specialists often did not have time for extensive one-on-one consultations. However, some farmers needed individualized recommendations for equipment adjustment, herbicide selection, or management advice to adopt or even try conservation tillage. Thus, small group, informal meetings were developed and conducted by extension assistants and agents at the local coffee shops.

Producers with conservation tillage experience were encouraged to attend and share tips and ideas from their farming enterprises to add to the "local personalized flavor." Attendance at these meetings was usually less than 20 , but the discussion and interaction was of tremendous help to those with specific questions. The informal atmosphere of the meetings allowed producers to interact freely with conservation tillage users, extension assistants, and extension agents.

\section{Planter and Sprayer Clinics}

Two other meeting formats included both sprayer and planter clinics. These programs generally involved calibration or adjustment of farmer-owned equipment and were often conducted in farm shops. These clinics were conducted by the extension assistants and a subject matter specialist. The planter clinic thrust was to show that existing planters could be used for conservation tillage with few, if any, modifications. Proper equipment adjustment was stressed regardless of the tillage system used.

\section{On-Farm Visits}

On-farm visits were frequently used to advise individual producers on the best conservation practices for their operation. This allowed one-on-one contact with the producer and allowed extension personnel to see the specific situation so they could make recommendations for pesticide use and/or equipment modification or adjustment. These visits were also made as concerns arose during the growing season and to monitor the demonstration plots.

\section{Media}

Many of the farmers having tillage plots were the subject of news releases prepared by the extension assistants. From 1985 to 1988 , approximately 80 news releases were prepared and sent to the extension agents for use in their weekly newspaper column or as stand-alone articles in the local papers. Five factsheets, brief and to the point, were written in response to commonly asked questions. Radio tapes were used to promote upcoming events and provide timely information to area producers.

\section{IMPACTS}

Meeting evaluations and the field and mail surveys were used to determine project impacts. As with many
Table 2. Survey of attendees at area conservation tillage meetings by year.

\begin{tabular}{lrrrrrr}
\hline & 1984 & 1985 & 1986 & 1987 & 1988 & 1989 \\
\hline $\begin{array}{l}\text { Number of meetings } \\
\text { Attendees }\end{array}$ & 10 & 8 & 10 & 14 & 14 & 17 \\
$\begin{array}{l}\text { Attendees filling out } \\
\quad \text { questionnaire }\end{array}$ & 425 & 875 & 900 & 825 & 1150 & 990 \\
$\begin{array}{l}\text { Plan to change tillage } \\
\text { practices }\end{array}$ & $75 \%$ & 803 & 432 & 421 & 565 & 495 \\
& & & $84 \%$ & $80 \%$ & $80 \%$ & $76 \%$ \\
\hline
\end{tabular}

Table 3. Use of tillage/planting systems from the field surveys in 1984 and 1988.

\begin{tabular}{|c|c|c|c|c|}
\hline \multirow[b]{3}{*}{ Tillage system } & \multicolumn{2}{|c|}{ System use, \% } & \multirow{2}{*}{\multicolumn{2}{|c|}{$\begin{array}{l}\text { Mean number of residue- } \\
\text { altering field operations } \\
\text { following harvest until the } \\
\text { subsequent crop was planted }\end{array}$}} \\
\hline & \multirow{2}{*}{$\begin{array}{c}1984 \\
(n=294)\end{array}$} & \multirow{2}{*}{$\begin{array}{c}1988 \\
(n=304)\end{array}$} & & \\
\hline & & & 1984 & 1985 \\
\hline Moldboard plow & 15.0 & 11.2 & 4.3 & 4.1 \\
\hline Chisel plow & 8.5 & 11.8 & 4.3 & 4.1 \\
\hline Disk & 68.7 & 62.5 & 3.8 & 3.5 \\
\hline Field cultivate & 5.4 & 7.2 & 2.6 & 2.7 \\
\hline Ridge-plant & 0.7 & 0.7 & 2.5 & 2.5 \\
\hline No-till & 1.7 & 6.6 & 1.2 & 1.4 \\
\hline
\end{tabular}

educational programs, the full impact will not be known for a number of years, because farmers slowly change tillage practices; they try new technologies on an experimental basis before implementing the practices on entire farms.

\section{Meeting Evaluations}

Averaged across $6 \mathrm{yr}, 80 \%$ of the farmers filling out an Area Conservation Tillage Meeting evaluation form indicated they would be changing their tillage programs as a result of the information presented (Table 2). Specific changes included plans to reduce the number of tillage operations, increase no-till planting into fields having soybean residue, and improve herbicide or fertility programs.

\section{Field Surveys}

Using the universal soil loss equation (USLE) as described by Wischmeier and Smith (1978), the average annual soil loss for 294 randomly selected fields surveyed in 1984 was $48.4 \mathrm{t} \mathrm{ha}^{-1}$. In 1988, the average annual soil erosion from 304 randomly selected fields that were surveyed was $38.1 \mathrm{t} \mathrm{ha}^{-1}, 21 \%$ less than in 1984. Assuming that the impact of the educational project was a reduction in soil loss of $10.3 \mathrm{t} \mathrm{ha}^{-1}$, the projected annual soil loss reduction in the 219000 -ha target areas would be $2.26 \mathrm{Mt}$.

The field survey information regarding tillage system use and the number of residue-altering operations (Table 3) supports the erosion reduction determined by the USLE calculations. For example, the use of no-till planting increased from $1.7 \%$ in 1984 to $6.6 \%$ in 1988 , nearly a threefold increase. Statewide, no-till use was $2.9 \%$ in 1984 and $4 \%$ in 1988 (CTIC, 1985, 1988). The average number of tillage operations for the moldboard plow, chisel, and disk systems tended to decrease slightly. 
Further, it apepars that farmers who were using the moldboard plow system made a shift toward a less intensive tillage system such as chiseling, and that some of the farmers previously disking either switched to using a field cultivator or no-till.

The reduction in the number of tillage operations and the increase in no-till planting resulted in an increase in residue cover. The percentage of fields classified as conservation tillage using the $30 \%$ residue cover criterion increased from $4.2 \%$ in 1984 to $5.1 \%$ in 1988 , a $21.4 \%$ increase in the target areas; whereas, there was a statewide decrease of $7.1 \%$ for the same time period (CTIC, 1985, 1988).

The tillage implement and the number of operations were used to determine fuel and labor requirements of the tillage/planting systems. For each of the fields surveyed in 1984 and 1988, fuel use was determined using the Nebraska Fuel Use Survey (Shelton et al., 1979). Average fuel use for the 304 fields surveyed in 1988 was $23.9 \mathrm{~L} \mathrm{ha}^{-1}$ compared with $30.7 \mathrm{~L} \mathrm{ha}^{-1}$ for the 294 fields in 1984, a decrease of $6.8 \mathrm{~L}$. Projected over the 219000 ha that were in the target areas, $1.47 \mathrm{ML}$ of fuel were saved annually. Assuming a cost of $\$ 0.24 \mathrm{~L}^{-1}$, this is an estimated annual savings of $\$ 350000$ because of reduced fuel use.

Because of fewer trips across the field and the shift toward less intensive tillage, there was a corresponding decrease in the amount of labor used in the target areas. The average labor use in $\mathbf{1 9 8 8}$ for tillage and planting operations was $1.61 \mathrm{~h} \mathrm{ha}^{-1}$. This was a decrease of $0.27 \mathrm{~h} \mathrm{ha}^{-1}$ from the average of $1.88 \mathrm{~h} \mathrm{ha}^{-1}$ determined from the 1984 survey. Projected over the target areas, the annual labor savings was $59400 \mathrm{~h}$. At $\$ 5.00 \mathrm{~h}^{-1}$, the value of the estimated labor savings was $\$ 297000$.

\section{Mail Surveys}

In $1984,14.9 \%$ of the mail survey respondents had tried or used a planting system with no preplant tillage (Dickey et al., 1987). In 1988, this response was $35.1 \%$. This increase is supportive of the no-till increase measured in the field surveys. The perceived use of conservation tillage from the mail survey in 1988 was $58 \%$, only slightly different than the 1984 response of $56.3 \%$. However, only $5.1 \%$ of 304 randomly selected fields surveyed in 1988 could be called conservation tillage, using the $30 \%$ residue cover criterion. This difference shows that perceptions about the use of conservation tillage may not accurately reflect actual field use. A similar conclusion was drawn from the 1984 surveys (Dickey et al., 1987).

Paired statistical comparisons between the 1988 and the corresponding 1984 responses for eight concepts that farmers might perceive as possible problems with conservation tillage systems indicated no significant difference in responses between years at the $10 \%$ level (Fig. 1). Paired statistical comparisons of how farmers perceived that conservation tillage might influence five factors in the farming operation also indicated no significant differences between years at the $10 \%$ level (Fig. 2). However, when comparing all the responses from

\begin{tabular}{|c|c|c|c|c|}
\hline Concepts ( $n=1984 \& 1988$, respectively) & $\underset{1}{\text { Major }}$ & $\begin{array}{c}\text { Degree of } \\
\text { Moderate } \\
2\end{array}$ & $\begin{array}{c}\text { Problem } \\
\text { Slight } \\
3\end{array}$ & $\begin{array}{c}\text { No } \\
4\end{array}$ \\
\hline $\begin{array}{l}\text { Cost and maintenance of equipment }(312,191) \\
\text { Row crop cultivation }(318,190) \\
\text { Disease, insect, rodent and weed control }(308,167) \\
\text { Planting the seed }(328,194) \\
\text { Application of herbicides and fertilizer }(324,194) \\
\text { Spreading crop residue behind combine }(344,211) \\
\text { Compaction of soil }(346,209) \\
\text { Different soil types and presence of } \\
\text { previous year's residue at harvest }(309,188)\end{array}$ & & & 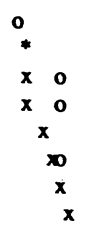 & $\begin{array}{l}0 \\
0 \\
0\end{array}$ \\
\hline
\end{tabular}

Fig. 1. Perception of degree of the problem that leaving more than a $30 \%$ residue cover would create for several concepts.

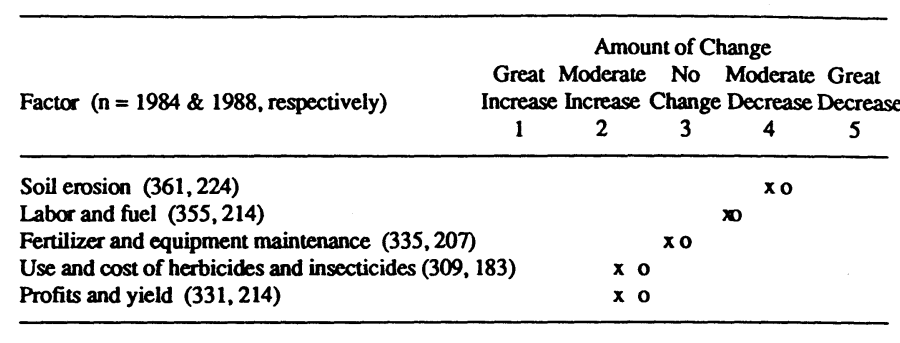

$x=1984$ response $\quad 0=1988$ response

Fig. 2 Perception of influence of conservation tillage practices on farming operations.

the 1984 and 1988 surveys, there was a trend for farmers to be more positive about conservation tillage in 1988 .

\section{CONCLUSIONS}

The education program was successful in enhancing the adoption of conservation tillage in selected high-priority target areas. Traditional and nontraditional extension methods were used to accomplish project objectives while promoting practices to conserve soil, energy, and labor. Targeting allowed efficient use of funds and resources to achieve substantial impacts in a relatively short period of time.

Between 1984 and 1988, improved residue management practices and shifts in tillage system use reduced average annual soil loss in the target areas by an estimated 2.27 Mt or $10.3 \mathrm{tha}^{-1}$. These shifts in tillage system use and the reduction in tillage operations reduced fuel consumption by an estimated $1.47 \mathrm{ML}$ annually or $6.8 \mathrm{~L} \mathrm{ha}^{-1}$. A corresponding projected reduction in labor of $0.27 \mathrm{~h}$ $\mathrm{ha}^{-1}$ or $59400 \mathrm{~h}$ annually occurred in the target areas. At $\$ 0.24 \mathrm{~L}^{-1}$ for fuel and $\$ 5.00 \mathrm{~h}^{-1}$ for labor, this resulted in a projected annual savings of almost $\$ 650000$ in the target areas.

The project also revealed some perceptions about conservation tillage. Future educational programs must be directed to an audience who already feel they are using conservation tillage and must emphasize the residue management aspects of conservation tillage. Surveys also indicated that myths and concerns still exist concerning conservation tillage. The project tended to lessen some of the producer concerns about problems arising from the increased residue levels associated with conservation 
tillage. Producers learned from field tours and equipment demonstration that conservation tillage is a practice they can implement on their own farms often using their existing equipment. Meetings, formal and informal, and clinics provided educational opportunities for producers to learn the management practices required to make conservation tillage work. The use of farmer cooperators and farmer speakers at meetings provided local encouragement necessary to enhance adoption.

Many farmers have developed conservation plans that include conservation tillage in response to the conservation compliance provisions of the 1985 Food Security Act. This act required approved conservation plans on highly erodible fields by 1990 for participation in many USDA programs. These farmers will need help in learning and using the management skills required for successful conservation tillage programs, because these plans are to be fully implemented by 1995 .

Even though the total use of conservation tillage in the target areas was only $5.1 \%$ in 1988 , these farmers have an advantage in that they have had several opportunities to see conservation tillage in their neighborhoods or have tried it themselves. These initial trials and corresponding shifts in attitudes will place these farmers in a better position to comply with their conservation plans.

Farmers who have not participated in educational programs will have more difficulty in achieving compliance. Failure to provide educational materials to this clientele group in a timely and informed manner will result in economic loss to the farmer and a credibility loss to education and action agencies. Future educational programs must build on the successes of the targeted approaches used in this project to enhance the adoption of conservation tillage.

\section{ACKNOWLEDGMENTS}

The authors wish to express their sincere thanks to the Nebraska Energy Office and the University of Nebraska Foundation for their financial support of this educational program, without which the program would not have been possible. Much appreciation is also expressed to the cooperating farmers and agribusiness representatives for their support of and participation in the educational activities.

\section{REFERENCES}

Bauder, J.W., and J.S. Hickman. 1988. Tillage committees: A local approach to effective extension education. J. Soil Water Conserv. 43:130-132.

Committee on Conservation Needs and Opportunities. 1986. Assessing conservation practices and land classification schemes. p. 75-94. In Soil conservation-assessing the national resources inventory. Vol. 1. Board on Agriculture, National Research Council, National Academy Press, Washington, DC.

Conservation Tillage Information Center. 1985. 1984 national survey of conservation tillage practices. Conservation Tillage Information Center, Ft. Wayne, IN.

Conservation Technology Information Center. 1988. 1988 national survey of conservation tillage practices. Conservation Technology Information Center, West Lafayette, IN.

Dickey, E.C., P.J. Jasa, B.J. Dolesh, L.A. Brown, and S.K. Rockwell. 1987. Conservation tillage: Perceived and actual use. J. Soil Water Conserv. 42:431-434.

Dickey, E.C., P.J. Jasa, D.P. Shelton, R.D. Grisso, and K. Glewen. 1991. Area conservation tillage meetings-a successful educational program. J. Agron. Educ. 20:115-119 (this issue)

Dillaha, T.A., B.B. Ross, S. Mostaghimi, C.D. Heatwale, and V.O. Shanholtz. 1988. Rainfall simulation: A tool for best management practice education. J. Soil Water Conserv. 43:288-290.

Jasa, P.J., and E.C. Dickey. 1990. Yield and conservation tillage. Conservation tillage. Univ. of Nebraska Coop. Ext. Conserv. Tillage Proc. 9:19-21.

Nebraska Natural Resources Commission. 1979. Section 208 Water Quality Management Plan for the State of Nebraska. NNRC, Lincoln, NE.

Nowak, P.J. 1985. The leadership crisis in conservation districts. J. Soil Water Conserv. 40:420-425.

Riehle, H. 1986. How to organize a successful conservation tillage conference. J. Soil Water Conserv. 41:28-29.

Rockwell, S.K., E.C. Dickey, and P.J. Jasa. 1990. The personal factor in evaluation use-a case study of a steering committee's use of a conservation tillage survey. Eval. Progr. Planning 13:389-394.

Shelton, D.P., K. VonBargen, N.W. Sullivan, D.E. Rolofson, and L.L. Bashford. 1979. Fuel use survey and energy management and conservation. Agric. Eng. Rep. 5. Inst. Agric. and Natural Resour., Univ. of Nebraska-Lincoln.

Swanson, N.P. 1965. Rotating-boom rainfall simulator. Trans. ASAE 8:71-72.

Wischmeier, W.H., and D.D. Smith. 1978. Predicting rainfall erosion losses-a guide to conservation planning. USDA Agric. Handb. 537. 